Article

\title{
Clinicopathologic Aspects of Squamous Cell Carcinoma of the Uterine Cervix: Role of PTEN, BCL2 and P53
}

\author{
Ali Yousif Babiker ${ }^{1,2}$, Ahmad Almatroudi ${ }^{1}$, Khaled S. Allemailem ${ }^{1}$, \\ Nazik Elmalaika O. S. Husain ${ }^{3}\left(\mathbb{D}\right.$, Mohamed A. Alsammani ${ }^{4}$, \\ Mohammed A. Alsahli ${ }^{1}$ and Arshad H. Rahmani ${ }^{1, *}$ \\ 1 Department of Medical Laboratories, College of Applied Medical Sciences, Qassim University, \\ Buraidah 51452, Saudi Arabia; alibabkr99@gmail.com (A.Y.B.); aamtrody@qu.edu.sa (A.A.); \\ k.allemailem@qu.edu.sa (K.S.A.); shly@qu.edu.sa (M.A.A.) \\ 2 Department of Histopathology and Cytology, College of Medical Laboratories Science, \\ University of Sciences and Technology, Omdurman P.O. Box 407, Sudan \\ 3 Department of Pathology, Faculty of Medicine, Omdurman Islamic University, \\ Omdurman P.O. Box 382, Sudan; nazikhusain@gmail.com \\ 4 Department of Obstetrics and Gynecology, College of Medicine, Qassim University, \\ Buraidah 51452, Saudi Arabia; m_sammani@yahoo.com \\ * Correspondence: ah.rahmani@qu.edu.sa
}

Received: 24 September 2018; Accepted: 27 October 2018; Published: 1 November 2018

check for updates

\begin{abstract}
Background: Squamous cell carcinoma (SCC) of the uterine cervix is a leading cause of morbidity and mortality among women. The alterations of Phosphatase and tensin homolog (PTEN), B-cell lymphoma 2 (Bcl2) and p53 expression seem to be significant in the development of various types of cancers. The altered expressions of PTEN, Bcl2 and p53 and their involvement in cancer of the uterine cervix are not well recognized. Aim: This study aimed at examining the expression patterns of PTEN, Bcl2 and p53 proteins and comparing them with the grade and stage of cervical cancer. Materials and Methods: Tissue blocks of SCC and ten cases of inflammatory lesions of the uterine cervix were examined immunohistochemically for the expression of PTEN, Bcl2 and p53 proteins. Results: Loss of PTEN expression was identified in $45.33 \%$ of cervical SCC and high expression was found in inflammatory lesions $(p \leq 0.05)$. PTEN expression was significantly associated with the clinical stage of SCC $(61.36 \%$ and $45.16 \%$ in stages I-II and III-IV, respectively) $(p<0.05)$, but not with the degree of differentiation of the SCC. The expression of $B c l 2$ was significantly high $(60 \%)$ in cancer cases than in control cases $(p<0.05)$. Bcl2 did not show any significant association with the histologic type and clinical stage of the SCC of the uterine cervix. The expression of p53 protein was significantly high $(57.33 \%))$ in cancer tissue, and no expression was noted in control cases $(p<0.05)$. Moreover, the expression pattern of p53 protein in cervical cancer tissue samples was not linked with the patient age, grade and stage of the cervical SCC $(p>0.05)$. Conclusion: The reduced expression of PETN and overexpressions of Bcl2 and p53 might play an indispensable role in carcinogenesis of cervical SCC. Moreover, a relationship was detected between PTEN expression and clinical stage of the cervical SCC.
\end{abstract}

Keywords: PTEN; Bcl2; p53; gene; immunohistochemistry; prognostic role; pathogenesis; carcinogenesis; SCC; cervical cancer 


\section{Introduction}

Cervical cancer is a cancer rising from the cervix and is a common malignancy of female gynecologic systems and contributes approximately $8 \%$ of altogether cancers [1]. The exact mechanisms behind development and progression have not been completely understood. Numerous factors are involved in the pathogenesis of cervical cancer, including human papillomavirus and alteration of cell signaling pathways. Previous findings have reported that the human papillomavirus infection is commonly detected in invasive cervical squamous cell carcinoma (SCC) [2]. However, with the introduction of screening programs based on population, the incidence and mortality rate of cervical cancer has been decreased [3]. However, still, it is vital to recognize potential biomarkers that could be used in the screening and inhibition of cervical cancer.

Tumor suppressor genes, as well as apoptotic genes, are vital for keeping genome integrity and the cell cycle. PTEN is a tumor-suppressor gene that encodes a phosphatase upstream of Akt in the phosphatidylinositol-3-kinase (PI3K) pathway [4], and its down-regulated activity has been noticed in many types of cancer [5-7]. AKT/protein kinase B is an essential downstream target of growth factor receptor tyrosine kinases that signal via PI3K [8-11]. Precisely, loss of PTEN causes activation of Akt, which in turn promotes anti-apoptotic as well as pro-cell cycle entry pathways supposed to be important in tumorigenesis [12]. Moreover, The PI3K/AKT cascade has been concerned in promoting cell survival downstream of extracellular stimuli $[13,14]$.

$P 53$ is a tumor suppressor gene and guardian of genome and it shows a pivotal role in determining the fate of cells exposed to DNA damage stimuli [15]. Wild-type p53 is a tumor suppressor protein that shows an important task in managing genomic stability through the cell cycle control and also shows a role in the induction of apoptosis when cell damage is beyond repair [16-18]. Studies advocate that p53 gene is the most frequently mutated tumor suppressor gene in human malignancy [19].

The B cell lymphoma-2 (Bcl2) family of proteins are vital controllers of apoptosis [20] and they are expressed in solid tumors, including breast, prostate, colorectal, lung, stomach, and ovarian cancers $[21,22]$. There is increasing proof to recommend that Bcl2-targeting therapy may be an effective treatment for cancers $[23,24]$.

Exploration of the relationship between the pattern of immunohistochemical expression of PTEN, Bcl2 and p53 and pathological grading and clinical staging of uterine cervix cancer was the aim of this study.

\section{Materials and Methods}

In this case-control study, 75 cases of squamous cell carcinoma of the uterine cervix were retrieved randomly from different histopathology departments in Khartoum State, Sudan. In this study, control cases $(n=10)$ as inflammatory lesions of uterine cervix cases were included, and the mean age of the patients was $46.0 \pm 12.0$ years old. The incidence of cervicitis was high in patients in the 4th decade. Tissue samples were fixed in $10 \%$ formalin; tissue was embedded in paraffin, and stained with hematoxylin and eosin for histopathological evaluation. Clinicopathologic characteristics, such as tumor size, differentiation grade, and stage, were recorded.

\subsection{Expressional Evaluation of PTEN, Bcl2, and P53 through Immunohistochemical Staining}

Concisely, formalin-fixed paraffin-embedded tissue sections were deparaffinized, rehydrated and rinsed in phosphate-buffered saline (PBS) ( $\mathrm{pH} 7.0)$ and the rest of the procedure was performed as the previously described method [25]. Blocking of endogenous peroxidase activity was done through $0.3 \%$ hydrogen peroxide in methanol for $20 \mathrm{~min}$. Antigen retrieval was done in citrate buffer ( $\mathrm{pH}$ 6.0) in a pressure cooker for $25 \mathrm{~min}$, and then sections were kept at room temperature for 10-15 min. Then, the blocking step was performed with protein block for $10 \mathrm{~min}$, and slices were washed. Expressional evaluation of PTEN, p53, and Bcl2 was examined through the streptavidin-biotin method. The monoclonal antibody of PTEN (PM 278AA, Biocare Medical, CA, USA), p53 (9D3DE3, 
Abcam, Cambridge, U.K.) and Bcl2 (PM003AA. Biocare Medical, USA) used as primary antibodies and sections were incubated for overnight at $4{ }^{\circ} \mathrm{C}$. Following incubation with secondary antibody (Abcam, Cambridge, U.K., Biotynylated Goat anti-mouse, ab 64259 lot GR 234312-2 lot GR 234312-2) for 60 min, followed by incubation with streptavidin-biotin enzyme (Streptavidin Peroxidase ab 64259) complex was applied for $45 \mathrm{~min}$ as the manufacturer instructions. Then, diaminobenzidine (DAB) (Abcam, Cambridge, U.K., ab 64259) chromogen was used, and sections were counterstained with hematoxylin and results were observed under a light microscope.

\subsection{Consideration of Positive and Negative Cases for Each Marker}

A total of five fields from each section were selected, and 100 cells from each area were counted and the mean percentage positivity was calculated. Expressions of PTEN, $p 53$, and Bcl2 were considered as the positive case if more than $5 \%$ of cells showed positivity and less than $5 \%$ positivity was taken as the negative case [26]. PTEN, Bcl2, p53 protein staining among the cervix tumor cases was either negative, weakly positive or strong positive.

\subsection{Statistical Analysis}

Markers' expression and its association with a histologic grade or clinical stage were analyzed by Chi-square $(\lambda)^{2}$. The $p$-Value of $p<0.05$ was considered statistically significant.

\section{Results}

\subsection{PTEN Protein Expression}

Expression of PTEN protein was noted in cancerous cases and inflammatory lesion of cervix (Figure 1a). Loss of PTEN expression was identified as $45.33 \%(34 / 75)$ in cervix cancer and a high expression was noted in control cases (Figure 1b) with $p<0.05$ (Table 1). PTEN expression was significantly associated with the clinical stage of the SCC of the uterine cervix $(61.36 \%$ and $45.16 \%$ in stages I-II and III-IV, respectively) $(p<0.05)$ (Table 1). No association was detected between the PTEN expression and grade of differentiation $(58.33 \%$ in the well differentiated, $55.88 \%$ in the moderately differentiated, $47.05 \%$ in the poorly differentiated) and age of the patients $(p>0.05)$ (Table 1$)$.

Table 1. Correlation between Phosphatase and tensin homolog (PTEN) and clinico-pathological features in cervical Squamous Cell Carcinoma (SCC).

\begin{tabular}{|c|c|c|c|c|}
\hline Variables & Total Cases & PTEN Positive & PTEN Negative & $p$-Value \\
\hline Cervical carcinoma & 75 & $41(54.66 \%)$ & $34(45.33 \%)$ & \multirow{2}{*}{$<0.05$} \\
\hline Inflammatory lesion & 10 & $10(100 \%)$ & $00(100 \%)$ & \\
\hline \multirow{2}{*}{$\begin{array}{c}\text { Age }(\text { In years }) \\
\leq 58 \text { years } \\
>58 \text { years }\end{array}$} & 31 & $18(58.06 \%)$ & $13(41.9 \%)$ & \multirow{2}{*}{$>0.05$} \\
\hline & 44 & $23(52.27 \%)$ & $21(47.72 \%)$ & \\
\hline \multicolumn{5}{|l|}{ Histological grades } \\
\hline Well differentiated & 24 & $14(58.33 \%)$ & $10(41.66 \%)$ & \multirow{2}{*}{$>0.05$} \\
\hline Moderately differentiated & 34 & $19(55.88 \%)$ & $15(44.11 \%)$ & \\
\hline Poorly differentiated & 17 & $8(47.05 \%)$ & 09 (52.94\%) & \\
\hline \multicolumn{5}{|l|}{ Clinical stage } \\
\hline I and II & 44 & $27(61.36 \%)$ & $17(38.63 \%)$ & $<0.05$ \\
\hline III and IV & 31 & $14(45.16 \%)$ & $17(54.83 \%)$ & \\
\hline
\end{tabular}




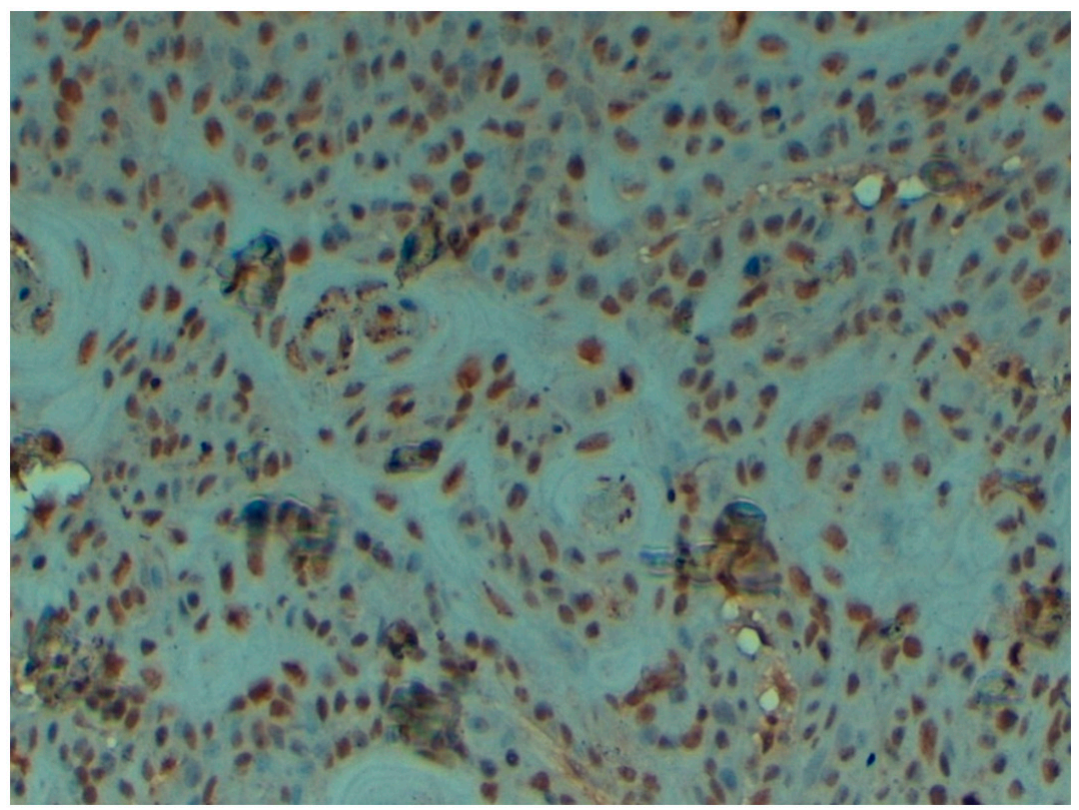

(a)



(b)

Figure 1. (a) Expression of PTEN protein in cervical squamous cell carcinoma (original magnification: $40 \times$ ). (b) Expression of PTEN protein in control cases (original magnification: $40 \times$ ).

\subsection{Bcl2 Expression}

The cytoplasmic expressions of Bcl2 protein were noted in 60\% (45/75) cases of cervical cancer tissue (Figure 2a). Whereas all control cases (inflammatory lesions) were negative or did not show any expression with $p<0.05$ (Figure $2 \mathrm{~b}$ ). Bcl 2 did not show any significant association with histologic type $(p>0.05)$, as well as clinical stage of the tumor $(p>0.05)$ (Table 2). Additionally, Bcl2 expression did not show any significant association with age of the patients $(p>0.05)$. 


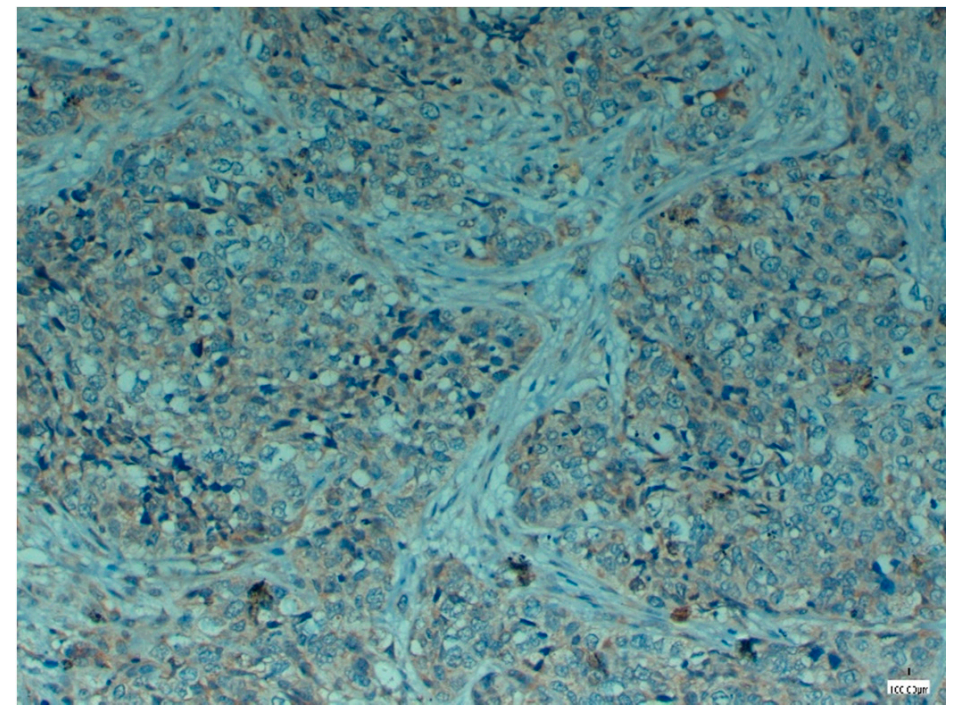

(a)

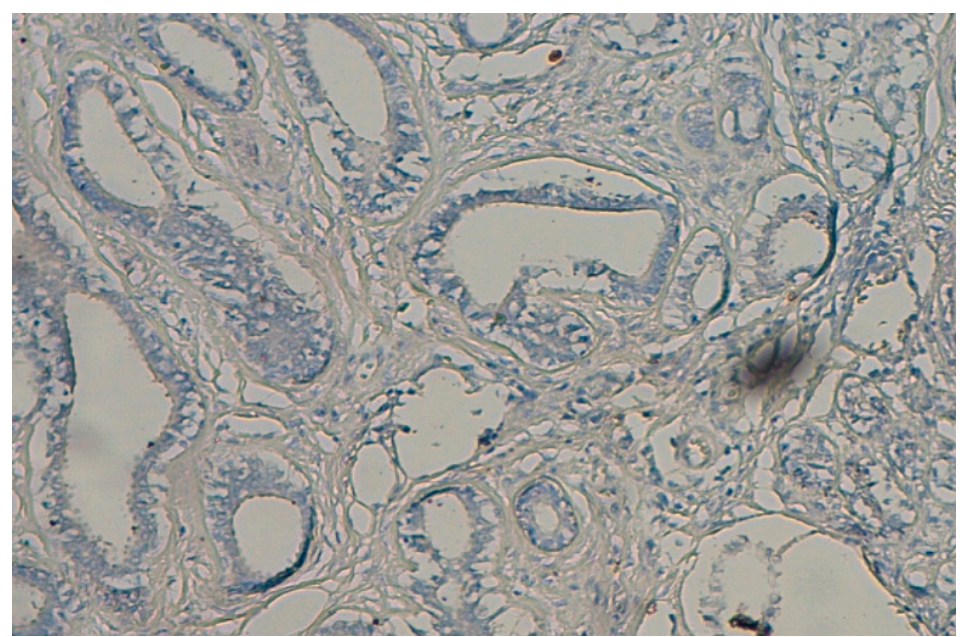

(b)

Figure 2. (a) Bcl2 protein is showing expression (cytoplasmic) in cervical SCC (original magnification: $40 \times$ ). (b) $\mathrm{Bcl} 2$ protein is not showing expression in control cases (original magnification: $40 \times$ ).

Table 2. Correlation between Bcl2 expression and clinico-pathological features of cervical SCC.

\begin{tabular}{|c|c|c|c|c|}
\hline Variables & Total Cases & Bcl2 Positive & Bcl2 Negative & $p$-Value \\
\hline Cervical carcinoma & 75 & $45(60 \%)$ & $30(40 \%)$ & \multirow{2}{*}{$<0.05$} \\
\hline Inflammatory lesion & 10 & $00(00 \%)$ & $10(100 \%)$ & \\
\hline \multirow{2}{*}{$\begin{array}{c}\text { Age (In years) } \\
\leq 58 \text { years } \\
>58 \text { years }\end{array}$} & 31 & $20(64.51 \%)$ & $11(35.38 \%)$ & \multirow{2}{*}{$>0.05$} \\
\hline & 44 & $25(56.81 \%)$ & $19(43.18 \%)$ & \\
\hline \multicolumn{5}{|l|}{ Histological grades } \\
\hline Well differentiated & 24 & $15(62.5 \%)$ & $09(37.5 \%)$ & \multirow{2}{*}{$>0.05$} \\
\hline Moderately differentiated & 34 & $21(61.76 \%)$ & $13(38.2 \%)$ & \\
\hline Poorly differentiated & 17 & $9(52.9 \%)$ & $08(47.05 \%)$ & \\
\hline \multicolumn{5}{|l|}{ Clinical stage } \\
\hline I and II & 44 & $28(63.63 \%)$ & $16(36.36 \%)$ & $>0.05$ \\
\hline III and IV & 31 & $17(54.83)$ & $14(45.16 \%)$ & \\
\hline
\end{tabular}




\subsection{P53 Expression}

The expression of p53 protein, which was mainly located in the nucleus (Figure 3a), was noted in $57.3 \%(43 / 75)$ cases (Table 3). The expression was high in cancer tissue, and no expression was observed in control cases (Figure $3 \mathrm{~b}$ ), and such difference of expression was statically significant $(p<0.05)$. The expression pattern of $\mathrm{p} 53$ protein in cervical cancer tissue samples was not associated with patient age, grade and stage of tumors $(p>0.05)$ (Table 3$)$.

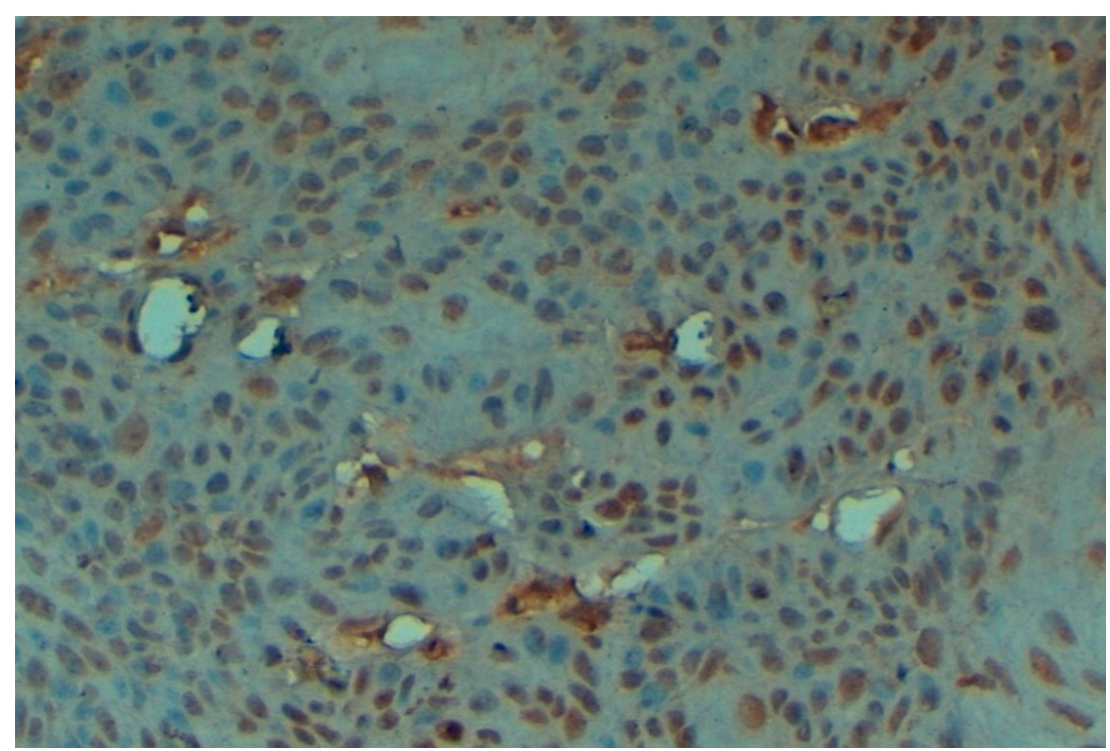

(a)

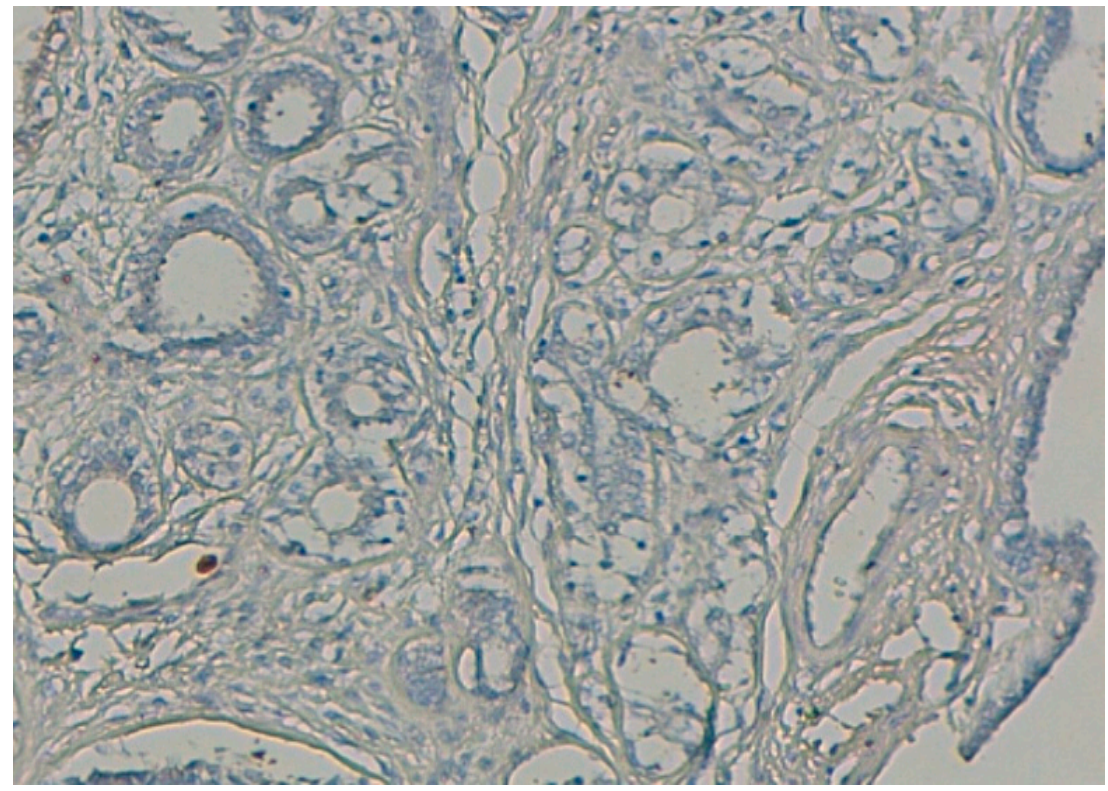

(b)

Figure 3. (a) p53 protein is showing expression (nuclear) in cervical SCC (original magnification: $40 \times$ ). (b) p53 protein is not showing expression in control cases (original magnification: $40 \times$ ). 
Table 3. Correlation between p53 expression and clinico-pathological features of cervical SCC.

\begin{tabular}{|c|c|c|c|c|}
\hline Variables & Total Cases & p53 Positive & p53 Negative & $p$-Value \\
\hline Cervical carcinoma & 75 & $43(57.33 \%)$ & $22(29.33 \%)$ & \multirow{2}{*}{$<0.05$} \\
\hline Inflammatory lesion & 10 & $00(00 \%)$ & $10(100 \%)$ & \\
\hline \multirow{2}{*}{$\begin{array}{c}\text { Age (In years) } \\
\leq 58 \text { years } \\
>58 \text { years }\end{array}$} & 31 & $17(54.83 \%)$ & $14(45.16 \%)$ & \multirow{2}{*}{$>0.05$} \\
\hline & 44 & $26(59.09 \%)$ & $18(40.90 \%)$ & \\
\hline \multicolumn{5}{|l|}{ Histological grades } \\
\hline Well differentiated & 24 & $15(62.5 \%)$ & $09(37.5 \%)$ & \multirow{2}{*}{$>0.05$} \\
\hline Moderately differentiated & 34 & $20(58.82 \%)$ & $13(38.2 \%)$ & \\
\hline Poorly differentiated & 17 & $08(47.05 \%)$ & $08(47.05 \%)$ & \\
\hline \multicolumn{5}{|l|}{ Clinical stage } \\
\hline I and II & 44 & $25(56.81 \%)$ & $16(36.36 \%)$ & $>0.05$ \\
\hline III and IV & 31 & $18(58.06)$ & $14(45.16 \%)$ & \\
\hline
\end{tabular}

\section{Discussion}

To the best of our knowledge, the prognostic role of PTEN protein expression through immunohistochemistry has not been evaluated in patients with cervix cancer earlier on Sudanese's patients. In the present study, it was perceived that PTEN protein expression was high in inflammatory lesions and loss of PTEN protein expression was noted in cervical cancer tissue samples, and such difference was significantly significant $(p<0.05)$. An earlier finding based on Chinese patients was in accordance with this finding and results showed that PTEN expression progressively decreased with the normal epithelium of the tissue to squamous cell carcinoma of the cervix [27]. Another recent study from other part of world reported that nuclear PTEN expression was detected in all cervicitis cases whereas 63/102 (62\%) cases of cervical cancer showed PTEN expression [28]. Moreover, the current study showed that loss of PTEN expression was significantly associated with clinical stage of the SCC of the uterine cervix (61.36 and $45.16 \%$ in stages I-II and III-IV, respectively) $(p<0.05)$. No associations were found between the PTEN expression and grade of differentiation and age of the patients $(p>0.05)$. In this regards, a previous finding also reported that PTEN protein expression was significantly correlated with the stage of the cervical SCC and lymph node metastasis [28] and positive PTEN immunostaining was associated with clinical stage and tumor size [27].

The $B c l 2$ gene belongs to the anti-apoptotic genes in the $B c l 2$ gene family, and its altered expression has been noticed in several types of tumors including carcinoma of the cervix. In the current study, it was reported that cytoplasmic expressions of Bcl2 protein were noted in $60 \%(45 / 75)$ cases of cervical cancer tissue. The expression pattern of Bcl2 was high in cancer cases than in control cases, and such a difference was statically significant $(p<0.05)$. There are scanty of data available on the expression of $\mathrm{Bcl} 2$ protein in cancer based on Sudanese patients. Previous study based on the oral cancer sample of Sudan revealed that expression of Bcl2 was found to be restricted to tumor cells in well and moderately differentiated tumors. There is no expression or undetectable expression of $\mathrm{Bcl} 2$ in basal cells [29]. The current findings are in keeping with an earlier study on cervical cancer from China, which reported that Bcl2 in the tissue of cervical cancer was significantly higher than that in normal cervical tissue [30]. Moreover, Bcl2 did not show any significant association with the histologic type $(p>0.05)$, the age of the patients and clinical stage of the cervical SCC $(p>0.05)$. These findings are similar to a previous result on cervical cancer, which reported that expression of Bcl2 had no significant association with the histologic type or clinical stage [31]. Another study said that Bcl 2 was expressed in $65 \%$ of the tumors and there was a statistically significant association between Bcl2 expression and poorer disease-free survival (DFS) and overall survival (OS) in stage IIB cases [32]. 
The $p 53$ gene is a tumor suppressor gene that encodes a 393-amino-acid nuclear DNA-binding phosphoprotein [33]. Studies have suggested that P53 gene is the most commonly mutated tumor suppressor gene in human malignancy and high expression has been noticed in oral cancers [34]. The current study finding reported that p53 protein expression was noted in $57.3 \%$ (43/75) cases. The expression was high in cancer tissue, and no expression was observed in control cases, and such difference of expression was statically significant $(p<0.05)$. P53 protein expression in cervical cancer tissue samples was not correlated with patient age, grade and stage of tumors $(p>0.05)$. An earlier report on cervical cancer stated that the protein expression level of p53 in the tumor tissues was significantly higher compared to that of the normal adjacent tissue [35]. Moreover, the same study reported that p53 protein expression in cervical cancer tissue samples was not correlated with the patient age, tumor size, or family history [35]. A study based on Sudanese patients reported that p53 was expressed in $19.3 \%$ of head and neck cancers whereas expression in benign tumors was low and only $4.0 \%$ benign cases showed expression [36].

In conclusion, our findings demonstrate that the loss of PTEN protein and overexpressions of $\mathrm{Bcl} 2$ and 553 protein play a vital role in the development and progression of cervix cancer.

Author Contributions: A.H.R. and N.E.O.S.H. conceived and designed the experiments; A.Y.B. and A.A. performed the experiments; K.S.A. and M.A.A. (Mohamed A. Alsammani) analysed the data. M.A.A. (Mohammed A. Alsahli) Editing \& Review.

Funding: This research received no external funding.

Acknowledgments: The authors acknowledge the Department of Medical Laboratories, College of Applied Medical Sciences, Qassim University, Saudi Arabia and Department of Pathology, College of Medicine, Omdurman Islamic University, Sudan for providing the samples, instruments facilities, chemicals and other items used in the study.

Conflicts of Interest: The authors have declared that no competing interests exist.

\section{References}

1. Ferlay, J.; Soerjomataram, I.; Ervik, M.; Dikshit, R.; Eser, S.; Mathers, C.; Rebelo, M.; Parkin, D.M.; Forman, D.; Bray, F. GLOBOCAN 2012 v1.0, Cancer Incidence and Mortality Worldwide: IARC CancerBase No. 11 [Internet]; International Agency for Research on Cancer: Lyon, France, 2013.

2. Walboomers, J.M.; Jacobs, M.V.; Manos, M.M.; Bosch, F.X.; Kummer, J.A.; Shah, K.V.; Snijders, P.J.; Peto, J.; Meijer, C.J.; Muñoz, N. Human papillomavirus is a necessary cause of invasive cervical cancer worldwide. J. Pathol. 1999, 189, 12-19. [CrossRef]

3. Zhang, W.N.; Li, W.; Wang, X.L.; Hu, Z.; Zhu, D.; Ding, W.C.; Liu, D.; Li, K.Z.; Ma, D.; Wang, H. CLDN1 expression in cervical cancer cells is related to tumor invasion and metastasis. Oncotarget 2016, 7, 87449-87461. [CrossRef] [PubMed]

4. Morgensztern, D.; McLeod, H.L. PI3K/Akt/mTOR pathway as a target for cancer therapy. Anticancer Drugs 2005, 16, 797-803. [CrossRef] [PubMed]

5. Song, M.S.; Salmena, L.; Pandolfi, P.P. The functions and regulation of the PTEN tumour suppressor. Nat. Rev. Mol. Cell Biol. 2012, 13, 283-296. [CrossRef] [PubMed]

6. Maeda, M.; Murakami, Y.; Watari, K.; Kuwano, M.; Izumi, H.; Ono, M. CpG hypermethylation contributes to decreased expression of PTEN during acquired resistance to gefitinib in human lung cancer cell lines. Lung Cancer 2015, 87, 265-271. [CrossRef] [PubMed]

7. Noro, R.; Gemma, A.; Miyanaga, A.; Kosaihira, S.; Minegishi, Y.; Nara, M.; Kokubo, Y.; Seike, M.; Kataoka, K.; Matsuda, K.; et al. PTEN inactivation in lung cancer cells and the effect of its recovery on treatment with epidermal growth factor receptor tyrosine kinase inhibitors. Int. J. Oncol. 2007, 31, 1157-1163. [PubMed]

8. Coffer, P.J.; Jin, J.; Woodgett, J.R. Protein kinase B (c-Akt): A multifunctional mediator of phosphatidylinositol 3-kinase activation. Biochem. J. 1998, 335, 1-13. [CrossRef] [PubMed]

9. Datta, S.R.; Brunet, A.; Greenberg, M.E. Cellular survival: A play in three Akts. Genes Dev. 1999, 13, 2905-2927. [CrossRef] [PubMed] 
10. Chan, T.O.; Rittenhouse, S.E.; Tsichlis, P.N. AKT/PKB and other D3 phosphoinositide-regulated kinases: Kinase activation by phosphoinositide-dependent phosphorylation. Annu. Rev. Biochem. 1999, 68, 965-1014. [CrossRef] [PubMed]

11. Cantley, L.C. The phosphoinositide 3-kinase pathway. Science 2002, 296, 1655-1657. [CrossRef] [PubMed]

12. Shah, A.; Swain, W.A.; Richardson, D.; Edwards, J.; Stewart, D.J.; Richardson, C.M.; Swinson, D.E.; Patel, D.; Jones, J.L.; O’Byrne, K.J. Phospho-Akt expression is associated with a favorable outcome in non-small cell lung cancer. Clin. Cancer Res. 2005, 11, 2930-2936. [CrossRef] [PubMed]

13. Franke, T.F.; Kaplan, D.R.; Cantley, L.C. PI3K: Downstream AKT action blocks apoptosis. Cell 1997, 88, 435-437. [CrossRef]

14. Wymann, M.P.; Pirola, L. Structure and function of phosphoinositide 3-kinases. Biochim. Biophys. Acta 1998, 1436, 127-150. [CrossRef]

15. Williams, A.B.; Schumacher, B. p53 in the DNA-Damage-Repair Process. Cold Spring Harb. Perspect. Med. 2016, 6, a026070. [CrossRef] [PubMed]

16. Lowe, S.W.; Bodis, S.; McClatchey, A.; Remington, L.; Ruley, H.E.; Fisher, D.E.; Housman, D.E.; Jacks, T. p53 status and the efficacy of cancer therapy in vivo. Science 1994, 266, 807-810. [CrossRef] [PubMed]

17. Yamashita, H.; Toyama, T.; Nishio, M.; Ando, Y.; Hamaguchi, M.; Zhang, Z.; Kobayashi, S.; Fujii, Y.; Iwase, H. p53 protein accumulation predicts resistance to endocrine therapy and decreased post-relapse survival in metastatic breast cancer. Breast Cancer Res. 2006, 8, R48. [CrossRef] [PubMed]

18. Rolland, P.; Spendlove, I.; Madjid, Z.; Rakha, E.A.; Patel, P.; Ellis, I.O.; Durrant, L. The p53 positive Bcl-2 negative phenotype is an independent marker of prognosis in breast cancer. Int. J. Cancer 2007, 120, 1311-1317. [CrossRef] [PubMed]

19. Nigro, J.M.; Baker, S.J.; Preisinger, A.C.; Jessup, J.M.; Hosteller, R.; Cleary, K.; Signer, S.H.; Davidson, N.; Baylin, S.; Devilee, P.; et al. Mutations in the p53 gene occur in diverse human tumour types. Nature 1989, 342, 705-708. [CrossRef] [PubMed]

20. Chipuk, J.E.; Moldoveanu, T.; Llambi, F.; Parsons, M.J.; Green, D.R. The BCL-2 family reunion. Mol. Cell 2010, 37, 299-310. [CrossRef] [PubMed]

21. Basu, A.; Haldar, S. The relationship between BcI2, Bax and p53: Consequences for cell cycle progression and cell death. Mol. Hum. Reprod. 1998, 4, 1099-1109. [CrossRef] [PubMed]

22. Bouchalova, K.; Kharaishvili, G.; Bouchal, J.; Vrbkova, J.; Megova, M.; Hlobilkova, A. Triple negative breast cancer: BCL2 in prognosis and prediction. Review. Curr. Drug Targets 2014, 15, 1166-1175. [CrossRef] [PubMed]

23. Oakes, S.R.; Vaillant, F.; Lim, E.; Lee, L.; Breslin, K.; Feleppa, F.; Deb, S.; Ritchie, M.E.; Takano, E.; Ward, T.; et al. Sensitization of BCL-2-expressing breast tumors to chemotherapy by the BH3 mimetic ABT-737. Proc. Natl. Acad. Sci. USA 2012, 109, 2766-2771. [CrossRef] [PubMed]

24. Oltersdorf, T.; Elmore, S.W.; Shoemaker, A.R.; Armstrong, R.C.; Augeri, D.J.; Belli, B.A.; Bruncko, M.; Deckwerth, T.L.; Dinges, J.; Hajduk, P.J.; et al. An inhibitor of Bcl-2 family proteins induces regression of solid tumours. Nature 2005, 435, 677-681. [CrossRef] [PubMed]

25. Rahmani, A.; Alzohairy, M.; Khadri, H.; Mandal, A.K.; Rizvi, M.A. Expressional evaluation of vascular endothelial growth factor (VEGF) protein in urinary bladder carcinoma patients exposed to cigarette smoke. Int. J. Clin. Exp. Pathol. 2012, 5, 195-202. [PubMed]

26. Rahmani, A.H.; Babiker, A.Y.; AlWanian, W.M.; Elsiddig, S.A.; Faragalla, H.E.; Aly, S.M. Association of cytokeratin and vimentin protein in the genesis of transitional cell carcinoma of urinary bladder patients. Dis. Markers 2015, 2015, 204759. [CrossRef] [PubMed]

27. Lu, D.; Qian, J.; Yin, X.; Xiao, Q.; Wang, C.; Zeng, Y. Expression of PTEN and survivin in cervical cancer: Promising biological markers for early diagnosis and prognostic evaluation. Br. J. Biomed. Sci. 2012, 69, 143-146. [PubMed]

28. Qi, Q.; Ling, Y.; Zhu, M.; Zhou, L.; Wan, M.; Bao, Y.; Liu, Y. Promoter region methylation and loss of protein expression of PTEN and significance in cervical cancer. Biomed. Rep. 2014, 2, 653-658. [CrossRef] [PubMed]

29. Rahmani, A.; Alzohairy, M.; Babiker, A.Y.; Rizvi, M.A.; Elkarimahmad, G.H. Clinicopathological significance of PTEN and bcl2 expressions in oral squamous cell carcinoma. Int. J. Clin. Exp. Pathol. 2012, 5, 965-971. [PubMed]

30. Zhang, C.; Chen, X.; Xia, K.; Dong, H. Expressions of NF-кBp50, p53 and Bcl-2 in cervical cancer and their relationship with human papillomavirus infection. Chin.-Ger. J. Clin. Oncol. 2006, 5, 451-453. [CrossRef] 
31. Munakata, S.; Watanabe, O.; Ohashi, K.; Morino, H. Expression of Fas ligand and bcl-2 in cervical carcinoma and their prognostic significance. Am. J. Clin. Pathol. 2005, 123, 879-885. [CrossRef] [PubMed]

32. Rajkumar, T.; Rajan, S.; Baruah, R.K.; Majhi, U.; Selvaluxmi, G.; Vasanthan, A. Prognostic significance of Bcl-2 and p53 protein expression in stage IIB and IIIB squamous cell carcinoma of the cervix. Eur. J. Gynaecol. Oncol. 1998, 19, 556-560. [PubMed]

33. Murphy, M. P53 Repression Elements in the Survivin and MAP4 Promoters; Scientific Report; Fox Chase Cancer Centre: Philadelphia, PA, USA, 2003; pp. 1-2.

34. Patil, N.N.; Wadhwan, V.; Chaudhary, M.; Nayyar, A.S. KAI-1 and p53 expression in oral squamous cell carcinomas: markers of significance in future diagnostics and possibly therapeutics. J. Oral Maxillofac. Pathol. 2016, 20, 384-389. [PubMed]

35. Liu, L.; Li, X.D.; Chen, H.Y.; Cui, J.S.; Xu, D.Y. Significance of Ebp1 and p53 protein expression in cervical cancer. Genet. Mol. Res. 2015, 14, 11860-11866. [CrossRef] [PubMed]

36. Abusail, M.S.; Dirweesh, A.M.; Salih, R.A.; Gadelkarim, A.H. Expression of EGFR and p53 in head and neck tumors among Sudanese patients. Asian Pac. J. Cancer Prev. 2013, 14, 6415-6418. [CrossRef] [PubMed]

(C) 2018 by the authors. Licensee MDPI, Basel, Switzerland. This article is an open access article distributed under the terms and conditions of the Creative Commons Attribution (CC BY) license (http://creativecommons.org/licenses/by/4.0/). 